\title{
Comparison of Grass and Legume Silages for Milk Production. 2. In Vivo and In Sacco Evaluations of Rumen Function
}

\author{
R. J. Dewhurst, ${ }^{\star}$ R. T. Evans,† N. D. Scollan, ${ }^{\star}$ J. M. Moorby, ${ }^{*}$ R. J. Merry, ${ }^{\star}$ and R. J. Wilkinsł \\ Institute of Grassland and Environmental Research, \\ *Plas Gogerddan, Aberystwyth SY23 3EB, U.K. \\ †Trawsgoed Research Farm, Aberystwyth SY23 4LL, U.K. \\ ¥North Wyke Research Station, Okehampton EX20 8SB, U.K.
}

\begin{abstract}
Two experiments were conducted to investigate the basis for higher voluntary intakes and increased $\alpha$-linolenic acid content in milk from cows offered clover silages. Six cows with rumen and duodenal cannulae were used in a four-period changeover-design experiment. Cows received $8 \mathrm{~kg} / \mathrm{d}$ of dairy concentrate and had ad libitum access to one of six silage treatments: grass, red clover, white clover, alfalfa, and 50/50 (dry matter basis) mixtures of grass with red clover or white clover. The rumen fermentability of grass, red clover, white clover, and grass/red clover silages was also evaluated in a nylon bag study. Legume silages led to increased dry matter intake and milk production in comparison with grass silage. There was no significant effect of legume silages on rumen $\mathrm{pH}$ and volatile fatty acid concentrations, but a significant increase in rumen ammonia concentration with the legume silages, reflecting their higher protein content. The inclusion of white clover or alfalfa silage, but not red clover silage, in diets led to an increase in molar proportions of isobutyric, iso-valeric, and $n$-valeric acids in comparison with diets based on grass silage. Rumen fill was significantly lower, and rumen passage rates were significantly higher for cows offered alfalfa or white clover silages. However, the markedly different particle size distribution of rumen contents with these feeds suggests very different mechanisms for the high intake characteristics: high rates of particle breakdown and passage with alfalfa, and high rates of fermentation and passage with white clover. Microbial energetic efficiency (grams microbial $\mathrm{N}$ per kilogram organic matter apparently digested in the rumen) was highest for cows offered alfalfa silage, intermediate for clover silage, and lowest for cows offered grass silage. These differences reflect the higher rumen outflow rates for legume si-
\end{abstract}

Received November 29, 2002.

Accepted April 1, 2003.

Corresponding author: R. J. Dewhurst; e-mail: Richard.Dewhurst @bbsrc.ac.uk. lages in comparison with grass silage. However, the effect of these differences on $\mathrm{N}$-use efficiency (feed to milk) was probably quite small in comparison with effects of $\mathrm{N}$ intake. Although the biohydrogenation of $\alpha$ linolenic acid was still high for red clover silage (86.1\% compared with $94.3 \%$ for grass silage), there was a $240 \%$ increase in the proportion of $\alpha$-linolenic acid passing through the rumen. This explains the increased recovery of $\alpha$-linolenic acid from feed into milk with diets based on red clover silage.

(Key words: legume, silage, rumen biohydrogenation, digesta kinetics, fatty acid)

Abbreviation key: $\mathbf{A}=$ alfalfa silage, $\mathbf{G}=$ grass silage, GRC = mixture of $\mathrm{G}$ and RC, GWC = mixture of $\mathrm{G}$ and $\mathrm{WC}, \mathbf{R C}=$ red clover silage, $\mathbf{W C}=$ white clover silage , RUN = rumen undegraded $\mathrm{N}$.

\section{INTRODUCTION}

Reduced input costs, particularly for fertilizer, and improvements in varieties mean that legume silages are of increasing interest to European farmers. White clover for grazing, and red clover for silage are indispensable elements of many organic rotations in NorthWest Europe. Earlier studies with legume silages identified increased intake and milk production in comparison with grass silages (e.g., Castle et al., 1983 with white clover; Thomas et al., 1985 with red clover; and Hoffman et al., 1998 with alfalfa). However, farmers increasingly have to consider factors other than yields, including effects of production systems on the environment and on product quality. The companion paper (Dewhurst et al., 2003) showed some additional benefits of legume silages in these areas. Red clover silage, in particular, led to increased levels of $\alpha$-linolenic acid in milk, whilst there was increased $\mathrm{N}$-use efficiency (at a given level of $\mathrm{N}$ intake) with white clover silage.

Earlier studies identified a number of physico-chemical attributes of legumes that may contribute to these effects. There are substantial differences in the gross morphology and cellular structures of grasses, white clover, red clover and alfalfa, which affect patterns of 
ingestion, mastication, rumination and particle size reduction (Wilson and Kennedy, 1996). Waghorn et al. (1989) demonstrated higher rates of passage from the rumen for fresh alfalfa in comparison with fresh grass. Moseley and Jones (1984) showed an increased rate of particle breakdown in the rumen of sheep offered dried white clover in comparison with dried perennial ryegrass. There have been no comparisons of rumen kinetics with silages prepared from grasses and legumes.

Red clover contains high levels of the enzyme polyphenol oxidase (EC 1.10.3.1), which converts native phenols to quinones, which bind with proteins. Albrecht and Muck (1991) showed that protein binding, whether from quinones or tannins, reduces proteolysis in the silo. Protein binding also reduces rumen proteolysis (Albrecht and Broderick, 1992) and this could also lead to an improvement in the conversion of feed $\mathrm{N}$ into milk $\mathrm{N}$ (Broderick et al., 2000).

The objective of this work was to understand the rumen mechanisms that lead to the differences between ryegrass silage and legume silages in feed intake, $\mathrm{N}$ utilization and fatty acid digestion, as a basis for further improvements through plant breeding or agronomy and ensiling techniques. In particular, we sought to investigate whether a reduction in rumen biohydrogenation explains the increased levels of $\alpha$-linolenic acid in milk produced by cows fed clover silages.

\section{MATERIALS AND METHODS}

\section{Experiment 1}

The feeds and feeding management design for this experiment are described in the companion paper (Dewhurst et al., 2003). Briefly, cows received $8 \mathrm{~kg} / \mathrm{d}$ of a standard dairy concentrate $(3 \mathrm{~kg}$ at each milking and $2 \mathrm{~kg}$ at $1200 \mathrm{~h}$ ), and ad libitum access to one of 6 silage treatments: grass $(\mathbf{G})$, red clover $(\mathbf{R C})$, white clover (WC), alfalfa (A), and 50/50, (DM basis) mixtures of G and RC (GRC) and G and WC (GWC). Each forage treatment comprised a proportional mixture of all cuts taken in the yr. One block of cows $(n=6)$ had previously been prepared with simple cannulae in the rumen (BarDiamond, Parma, ID) and duodenum and were housed in individual stalls with free access to forage, water and mineralized licks (Rockies Baby Red; Tithebarn Ltd., Cheshire, UK). Mean initial DIM was 76 (SD = 36.0) and mean initial $\mathrm{BW}$ was $577(\mathrm{SD}=44.1) \mathrm{kg}$. Cows were milked twice per day at 0730 and $1600 \mathrm{~h}$. An additional measurement period was used with these cows, so the design was a 4-period incomplete changeover-design.

Each experimental period lasted for $28 \mathrm{~d}$ and measurements were made in the penultimate (diet digestibilities) and final wk of each period. Rumen $\mathrm{pH}$ was recorded manually at $0800,1000,1100,1200,1300$, 1500 , and $1700 \mathrm{~h}$. Samples of rumen fluid were also taken using automated equipment, at 2-h intervals throughout the d (12 samples/cow), acidified and analyzed for content of ammonia and VFA. Samples of duodenal digesta were taken over the following two d using the automated equipment described by Evans et al. (1981). Ytterbium acetate (mean $651(\mathrm{SD}=33.4) \mathrm{mg}$ $\mathrm{Yb} / \mathrm{d}$ ) was infused into the rumen continuously as a marker to allow estimation of flows at the duodenum.

Rumen emptying was undertaken, by hand, on the final two $d$ of each period. All cows were emptied at $0900 \mathrm{~h}$ (prefeeding) on the penultimate d, and at 1300 $\mathrm{h}$ ( $4 \mathrm{~h}$ postfeeding) on the final d. Samples (5\%) of rumen contents were taken throughout the emptying procedure for analysis and rumen contents weighed and returned to all cows within 30 min of commencement. Rumen contents were sub-sampled and analyzed for content of DM and NDF. The particle size distribution of rumen contents was determined by wet-sieving (Moseley and Jones, 1984), using sieve apertures of $4.00,2.00,1.00,0.50,0.25$, and $0.106 \mathrm{~mm}$. Liquid-phase rumen bacteria were separated from rumen contents by differential centrifugation $(1600 \times g$ for $15 \mathrm{~min}$ and $30,000 \times g$ for 25 min; Siddons et al., 1982). A further sample of rumen contents was used to prepare solidassociated bacteria. This sample was washed twice in saline $(9 \mathrm{~g} / \mathrm{L} ; 750 \mathrm{~g}$ rumen contents washed in $1.5 \mathrm{~L})$ to remove loosely adherent bacteria. Washed fiber was then suspended in saline and pummeled to detach some of the solid-associated bacteria. This procedure is described by Merry and McAllan (1983), except that we used approximately $250 \mathrm{~g}$ of washed fiber and $320 \mathrm{ml}$ of saline. Solid-associated bacteria were isolated by the differential centrifugation procedures described above. The average composition of solid- and liquid-associated bacteria was used for calculations of microbial $\mathrm{N}$ content in duodenal digesta.

\section{Experiment 2}

A nylon bag study was conducted with the forages offered in Experiment 2 of the companion paper (Dewhurst et al., 2003): grass silage, white clover silage, red clover silage and a 50/50 (DM basis) mixture of grass and red clover silages. Three nonlactating cows which had previously been prepared with rumen cannulae (Bar-Diamond, Parma, ID) were offered a basal diet of $6 \mathrm{~kg} / \mathrm{d}$ grass hay (65.4\% NDF and 10.3\% CP in DM) and $2 \mathrm{~kg} / \mathrm{d}$ concentrates $(35.0 \% \mathrm{NDF}$ and $20.7 \% \mathrm{CP}$ in DM), in equal meals at 0900 and $1700 \mathrm{~h}$. Forages were dried at $45^{\circ} \mathrm{C}(48 \mathrm{~h})$ and chopped to pass through a 4$\mathrm{mm}$ aperture. Five-g samples were weighed into nylon bags $(23 \times 9 \mathrm{~cm}$; pore size of $40 \mu \mathrm{m})$. Duplicate bags 
were incubated in each of the cows for $0,2,4,8,16,24$, and $48 \mathrm{~h}$ periods. On removal from the cows the bags were immediately immersed in cold water and then machine-washed using a cold rinse cycle. Bags were dried at $60^{\circ} \mathrm{C}(16 \mathrm{~h})$ and duplicates were bulked for $\mathrm{N}$ analysis. Additional samples were used to determine water solubility by washing ten volumes of cold tap water through samples held in a Whatman 41 filter paper.

\section{Analysis}

The methods (and results) of analysis of feed samples are described in the companion paper (Dewhurst et al., 2003). Ammonia and VFA concentrations in rumen fluid, as well as ytterbium concentrations in duodenal digesta, were determined according to the procedures described by Dewhurst et al. (2000). Cytosine was used as microbial marker in duodenal digesta and was determined in rumen microbes and duodenal digesta using a HPLC method (Cozzi et al., 1993). Concentrations of fatty acids in samples of feed and digesta were determined using the procedure of Sukhija and Palmquist (1988). All N analysis was conducted using a Leco FP $428 \mathrm{~N}$ analyzer.

\section{Statistics}

Measurements were lost from one cow that was lame at the end of the first period. One cow was lost from the experiment at the end of the second period (digestive upset), but was replaced by a spare animal for periods 3 and 4. Rumen measurements were lost for one cow that became lame in period 4 . Two of the duodenal flow estimates for period 4 were unrealistically high (apparent digestibilities were over 3 standard deviations below the mean) and so were excluded from the statistical analysis.

Flows of DM at the duodenum were estimated by dividing the concentration of $\mathrm{Yb}$ in digesta $\mathrm{DM}$ by the quantity of $\mathrm{Yb}$ infused each $\mathrm{d}$. Rumen biohydrogenation of linoleic acid $\left(\mathrm{C}_{18: 2}\right)$ and $\alpha$-linolenic acid $\left(\mathrm{C}_{18: 3}\right)$ was calculated in two ways: 1 ) from the change in the levels of these fatty acids (as a proportion of total $\mathrm{C}_{18}$ fatty acids) between feed and duodenal digesta (Wu et al., 1991), and 2) based on the intake and duodenal flow of the specific fatty acid ((feed-flow)/feed).

Results were analyzed by analysis of variance using the REML (residual maximum likelihood) directive of Genstat for Windows (Lawes Agricultural Trust, 2000). The analysis generally used mean values for each cow and period. The fixed model had 6 treatments with an embedded $2 \times 2$ factorial (50 or 100\% legume silage $\times$ red clover or white clover) compared with two other treatments ( $\mathrm{G}$ and $\mathrm{A})$. The random model was Period $\times$ Cow. Least-significant difference analysis was used for further comparison within the 3 "Group" means (G vs. A and G vs. clover-containing diets). The effect of time and its interaction with other fixed factors was considered only for the rumen volume and rumen particle size distribution results. Rumen particle size distribution was analyzed according to proportions of DM in 3 classes ( $>2 \mathrm{~mm}, 0.106$ to $2 \mathrm{~mm}$, and $<0.106 \mathrm{~mm}$ ).

Degradation curves for DM were fitted to dacron bag data using the model of Dhanoa (1988), which simultaneously fits a lag phase and degradation parametersthe immediately soluble fraction (a), the fraction which disappears over time (b), and the rate of disappearance of that fraction (c). This model did not provide a good fit for $\mathrm{N}$ degradation of GS, so the model of Ørskov and McDonald (1979), without a lag phase, was used for $\mathrm{N}$ degradation results.

\section{RESULTS}

\section{Experiment 1}

Cows fed diets containing clover silages had higher DM intakes than cows fed grass silage $(P<0.01)$. In contrast to results with the other cows, the fistulated cows showed higher silage DM intakes for mixtures of grass silage and clover silage (Table 1). There were only small effects of treatments on milk yields (Table 1), with the most significant effect being the increased milk yields for WC in comparison with RC.

Rumen measurements are shown in Table 2. Rumen conditions were extremely stable for all of the diets, with mean $\mathrm{pH}$ in the range 6.3 to 6.6 (Table 2). There were statistically significant, but small, effects on total VFA concentrations and molar proportions. Concentrations of $n$-butyric acid and $n$-valeric acid were increased at the higher level of clover inclusion. The most obvious effect was higher concentrations and molar percentages of iso-butyric acid, iso-valeric, and $n$-valeric acids with white clover in comparison with red clover silage. The higher $\mathrm{N}$ content of diets based on $100 \%$ clover silage resulted in significantly higher rumen ammonia concentrations than with $50 \%$ clover silage.

Results of the rumen emptying study are given in Table 3 . There were no significant diet $\times$ time interaction effects on rumen fill. There was a significantly lower quantity of rumen contents, both DM and NDF, when cows were offered white clover silages in comparison with red clover silage. Cows consuming A had significantly less rumen contents (fresh weight) than cows consuming $\mathrm{G}(P<0.05)$. White clover silage led to a high proportion of large particles $(>2 \mathrm{~mm})$ and a low proportion of intermediate particles $(0.106$ to $2 \mathrm{~mm})$ as compared to RC. Alfalfa silage led to a low proportion 
Table 1. Effects of legume silages on feed intake and milk production (Experiment 1).

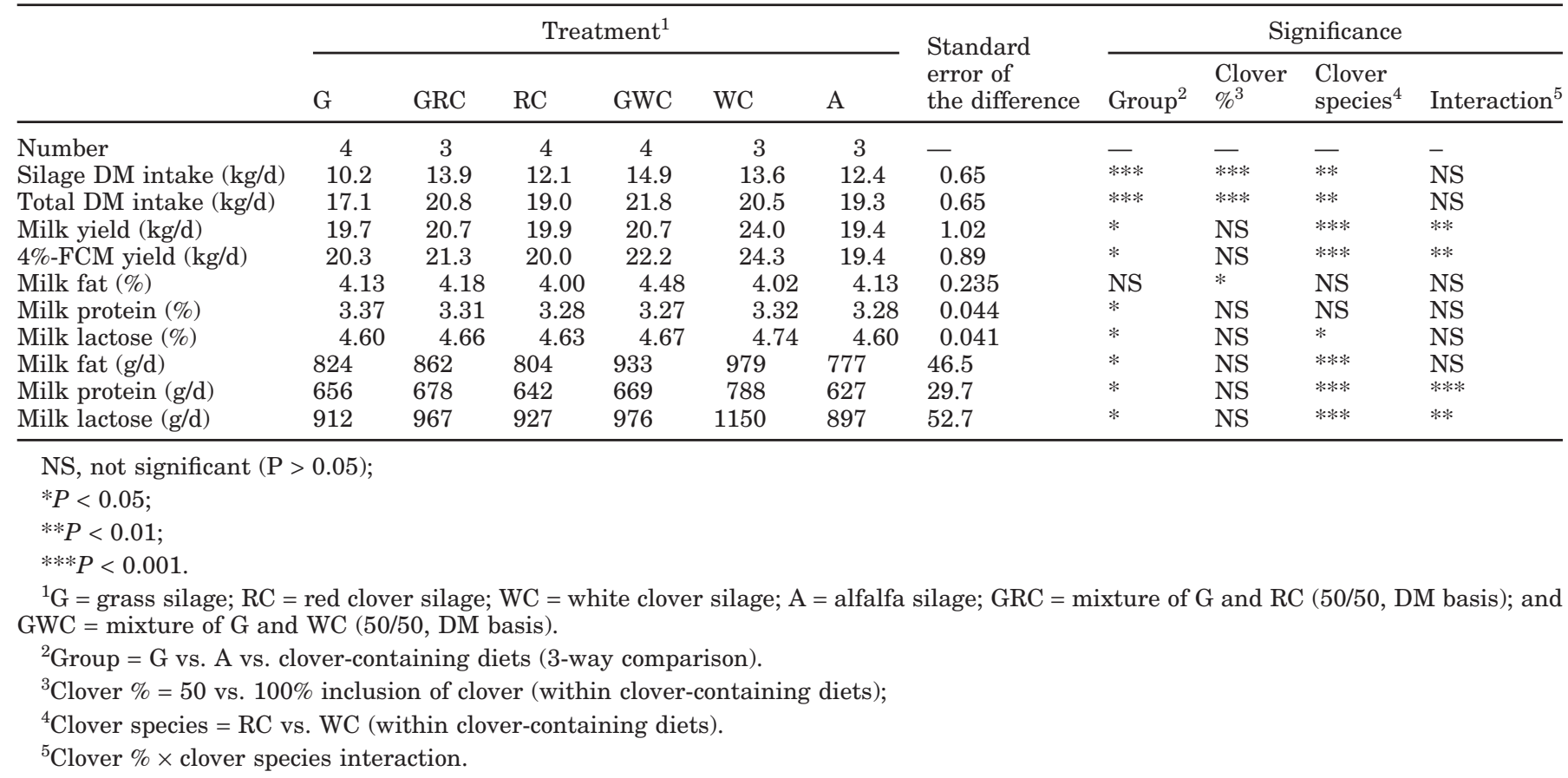

of large particles $(P<0.05)$ and a high proportion of intermediate particles $(P<0.05)$ in comparison with $\mathrm{G}$. The effects of forage treatments on nutrient flows from the rumen are shown in Table 4. Both legume silages led to higher flows of NAN at the duodenum, though the effect was greatest for WC. The increase in duodenal NAN flow generally paralleled increased $\mathrm{N}$ intake, though flows with diet A were less than expected on

Table 2. Effects of legume silages on rumen $\mathrm{pH}$, volatile fatty acids and ammonia (Experiment 1).

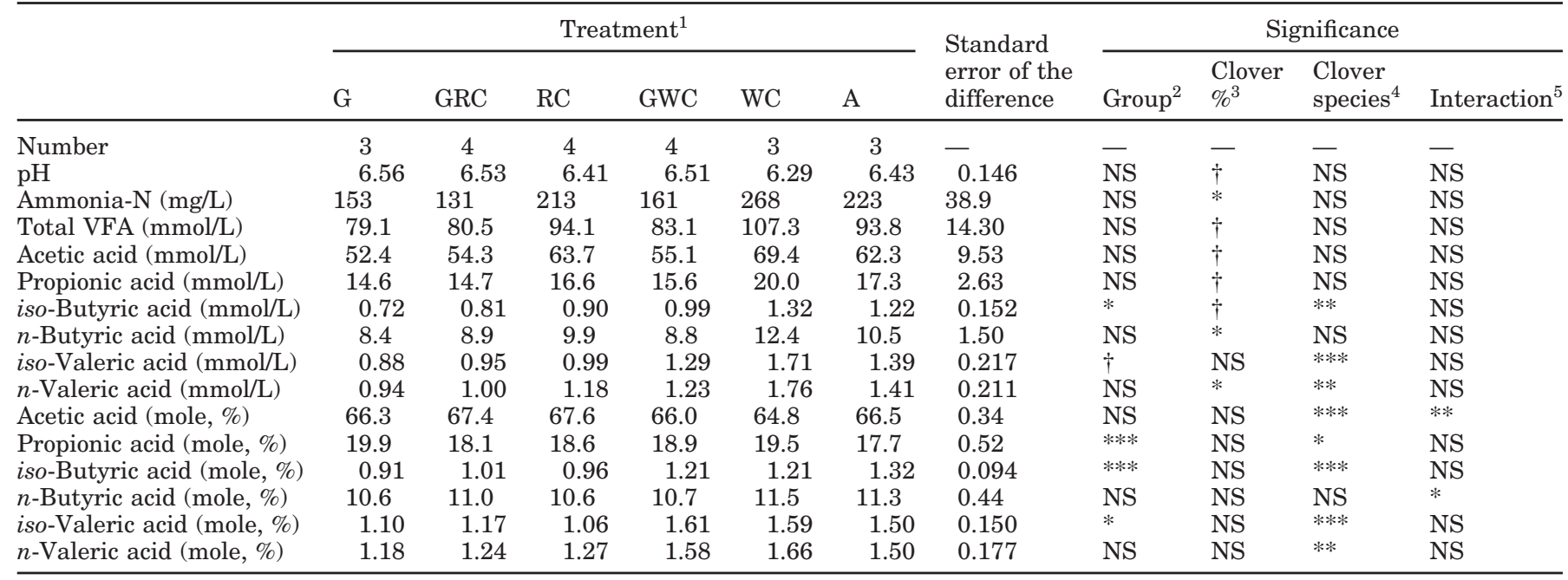

${ }^{1} \mathrm{G}=$ grass silage; $\mathrm{RC}=$ red clover silage; $\mathrm{WC}=$ white clover silage; $\mathrm{A}=$ alfalfa silage; $\mathrm{GRC}=$ mixture of $\mathrm{G}$ and $\mathrm{RC}$ (50/50, $\mathrm{DM}$ basis); GWC $=$ mixture of $\mathrm{G}$ and WC (50/50, DM basis).

NS, not significant $(\mathrm{P}>0.1) ; \dagger, P<0.1 ; *, P<0.05 ; * *, P<0.01 ; * * *, P<0.001$.

${ }^{2}$ Group $=$ G vs. A vs. clover-containing diets (3-way comparison).

${ }^{3}$ Clover $\%=50$ vs. $100 \%$ inclusion of clover (within clover-containing diets).

${ }^{4}$ Clover species $=\mathrm{RC}$ vs. WC (within clover-containing diets).

${ }^{5}$ Clover $\% \times$ clover species interaction. 
Table 3. Effects of legume silages on rumen fill and particle size distribution (Experiment 1). In each case, the upper row of values are for samples taken at $0900 \mathrm{~h}$, the lower row are for samples taken at $1300 \mathrm{~h}$.

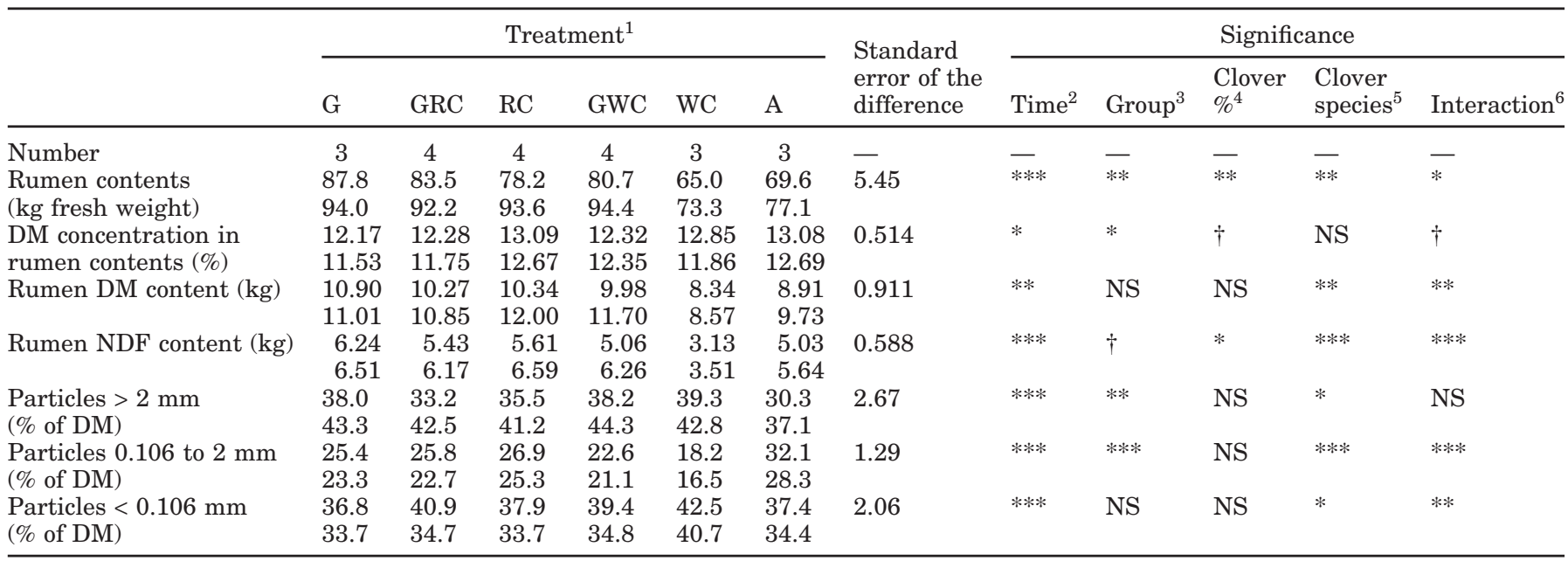

${ }^{1} \mathrm{G}=$ grass silage; $\mathrm{RC}=$ red clover silage; $\mathrm{WC}=$ white clover silage; $\mathrm{A}=$ alfalfa silage; $\mathrm{GRC}=$ mixture of $\mathrm{G}$ and $\mathrm{RC}(50 / 50, \mathrm{DM}$ basis $)$; $\mathrm{GWC}=$ mixture of $\mathrm{G}$ and WC (50/50, DM basis).

NS, not significant $(\mathrm{P}>0.1) ; \dagger, P<0.1 ; *, P<0.05 ; * *, P<0.01 ; * * *, P<0.001$.

${ }^{2}$ Sampling time (09.00 vs. $13.00 \mathrm{~h}$ );

${ }^{3}$ Group $=\mathrm{G}$ vs. A vs. clover-containing diets (3-way comparison);

${ }^{4}$ Clover $\%=50$ vs. $100 \%$ inclusion of clover (within clover-containing diets);

${ }^{5}$ Clover species $=$ RC vs. WC (within clover-containing diets);

${ }^{6}$ Clover $\% \times$ clover species interaction. There were no significant treatment $\times$ time interactions.

this basis. There were no significant differences in $\mathrm{N}$ degradability, though red clover $\mathrm{N}$ was numerically least degradable. Microbial $\mathrm{N}$ flow and microbial energetic efficiency (g MN/kg ADOMR) were lower for cows offered grass silage than for cows offered legume si- lages. Microbial N yield was significantly higher for WC in comparison with RC.

Outflow rates from the rumen were calculated by expressing duodenal DM flow as a proportion of the rumen DM pool, estimated from the rumen emptying

Table 4. Effects of legume silages on flows of nutrients and microbial protein to the duodenum (Experiment 1).

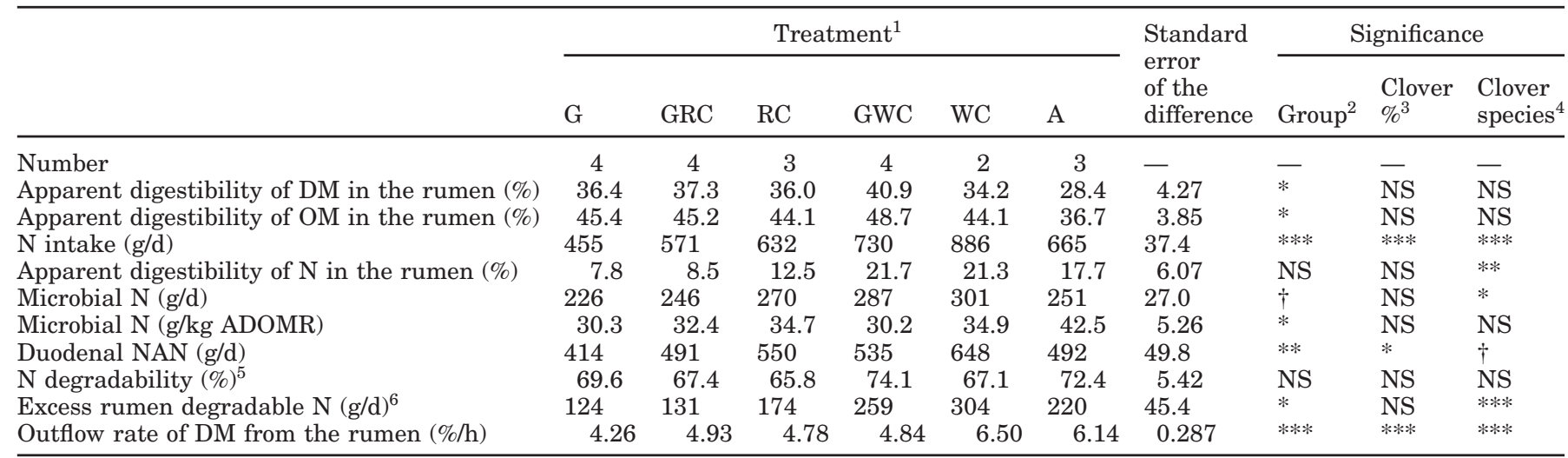

${ }^{1} \mathrm{G}=$ grass silage; $\mathrm{RC}=$ red clover silage; $\mathrm{WC}=$ white clover silage; $\mathrm{A}=$ alfalfa silage; $\mathrm{GRC}=$ mixture of $\mathrm{G}$ and $\mathrm{RC}(50 / 50, \mathrm{DM}$ basis $) ;$ $\mathrm{GWC}=$ mixture of $\mathrm{G}$ and $\mathrm{WC}(50 / 50, \mathrm{DM}$ basis); $\mathrm{ADOMR}=\mathrm{OM}$ apparently digested in the rumen.

${ }^{2}$ Group $=$ G vs. A vs. clover-containing diets (3-way comparison);

${ }^{3}$ Clover $\%=50$ vs. $100 \%$ inclusion of clover (within clover-containing diets);

${ }^{4}$ Clover species $=$ RC vs. WC (within clover-containing diets). There were no significant clover $\% \times$ clover species interactions.

${ }^{5}$ Estimates assume that endogenous- $\mathrm{N}$ was $2.8 \mathrm{~g} / \mathrm{kg}$ DM intake (Bartram, 1987).

${ }^{6}$ Rumen degradable $\mathrm{N}$ minus microbial $\mathrm{N}$.

NS, not significant $(\mathrm{P}>0.1) ; \dagger, \mathrm{P}<0.1 ; * P<0.05 ; * *, P<0.01 ; * * *, P<0.001$. 
studies. Both alfalfa silage and white clover silage led to higher outflow rates from the rumen, whilst grass silage led to the lowest rumen outflow rates $(P<0.01$ for the difference between $\mathrm{G}$ and $\mathrm{A}$ ). The effects of forage treatments on the biohydrogenation of linoleic acid and $\alpha$-linolenic acid in the rumen are shown in Table 5 . There were significant effects of increasing the percentage of clover and significant differences between the clover species on biohydrogenation. The biohydrogenation of linoleic acid was significantly lower with WC in comparison with $\mathrm{RC}$, whilst the biohydrogenation of $a$ linolenic acid was significantly lower with RC in comparison with WC.

\section{Experiment 2}

The solubility of $\mathrm{N}$ in the different legume silages, based on water extraction and filtration through filter paper, are shown in Table 6. Fitted degradation parameters for DM and $\mathrm{N}$ are shown in Tables 7 and 8 respectively. It is immediately apparent that $\mathrm{N}$ solubility values in Table 6 are not consistent with $\mathrm{N}$ solubility values (the "a" fraction) from the nylon bag study (Table 8 ), where red clover $\mathrm{N}$ solubility was $10 \%$ lower for red clover silage compared to that of white clover or grass silages.

\section{DISCUSSION}

The tendency for higher rumen VFA concentrations with white clover silage reflects the higher fermentation rate of this feed (Table 7). The slightly lower propionate molar proportions in the rumens of cows offered legume silages are in agreement with the results of earlier studies with fresh herbage (Beever et al., 1986; 1987). The increase in molar proportions of iso-butyric, iso-valeric, and $n$-valeric acids with diets based on alfalfa silage and white clover silage reflect the greater excess RDP supply with these diets (Table 4).

Analysis of meal information with these feeds (Dewhurst et al., 2003: Table 7) showed that legume silages had little effect on the number of forage meals each $d$. The increased rumen passage rates of legume silages, and lower rumen fill with WC and A, were associated with cows having larger forage meals, though the number of meals was not significantly different. The high voluntary intakes of alfalfa silage and white clover silage were obtained despite low rumen fill for cows offered these diets and were accompanied by much higher passage rates from the rumen. Grass silage led to the lowest voluntary intakes and highest rumen fills. The particle size distributions of rumen contents (Table 3) confirm differences in the way in which the different forages are broken down in the rumen. The differences in the patterns of particle distribution in rumen contents of cows offered grass or white clover silages were similar to those recorded in earlier studies with dried forages (Moseley and Jones, 1984).

The degradation, passage and digestibility results for different forages combine to explain effects on intake and production: alfalfa silage, white clover silage, and grass silage typify three distinct situations. Red clover silage and grass/legume silage mixtures behaved quite similarly to grass silage. It is suggested that digesta kinetics were strongly influenced by the persistent mat that develops when feeding G or RC. Alfalfa silage particles break down rapidly, so that despite a high passage rate from the rumen, there is a high proportion of particles less than $2 \mathrm{~mm}$ in the rumen. The high passage rate of particles from the rumen facilitates high intakes. However, the high passage rate and inherent lower digestibility of alfalfa silage combine to influence milk yields, giving lower values than might be predicted from increased intakes. The apparent digestibility of DM in the rumen was notably low for cows offered alfalfa silage.

Conversely, the degradation characteristics, digesta passage rates, and rumen particle size distribution of rumen contents from cows offered white clover silage suggest a different mechanism. The high intakes of white clover silage are made possible by inherently higher fermentation rates (Table 7). Unfermented feed is able to leave the rumen once particles have been reduced in size and become less buoyant because fermentation (gas production) is complete (Baumont and Deswysen, 1991). The reductions in buoyancy and particle sizes are generally faster in rapidly-fermented feeds, such as white clover.

The inherently higher fermentability of white clover silage means that cows are able to derive more nutrients and so milk yields were much higher with this forage (Table 1). Rumen fill was not limiting productivity from white clover silage: cows produced the most milk despite having less than $80 \%$ of the rumen contents of cows offered grass silage-based diets. The situation with grass silage is very different. The low inherent rates of fermentation of grass silage (Table 7) mean that high digestibility of grass silage is dependent upon longer periods of fermentation in the rumen, which probably result from entrapment in the long-fiber rumen mat in grass-fed cows. However, increased rumen retention times mean that milk yields are limited by low intakes (Table 1; Dewhurst et al., 2003: Table 7).

All of the legume silages led to increases in the flow of NAN at the duodenum (Table 4). Some of this increase is explained by the tendency for increased flows of microbial N. Microbial energetic efficiency (g microbial $\mathrm{N}$ per $\mathrm{kg} \mathrm{OM}$ apparently digested in the rumen) 
Table 5. Effects of legume silages on rumen biohydrogenation $(\dagger)$ of polyunsaturated C18 fatty acids (Experiment 1$)$.

\begin{tabular}{|c|c|c|c|c|c|c|c|c|c|c|c|}
\hline & \multicolumn{6}{|c|}{ Treatment $^{1}$} & \multirow{2}{*}{$\begin{array}{l}\text { Standard } \\
\text { error of } \\
\text { the difference }\end{array}$} & \multicolumn{4}{|c|}{ Significance } \\
\hline & $\mathrm{G}$ & GRC & $\mathrm{RC}$ & GWC & WC & A & & Group $^{2}$ & Clover $\%^{3}$ & Clover species ${ }^{4}$ & Interaction $^{5}$ \\
\hline Jumber & 4 & 3 & 4 & 4 & 3 & 3 & - & - & - & - & - \\
\hline Total intake of $\mathrm{C}_{18}$ fatty acids $(\mathrm{g} / \mathrm{d})$ & 301 & 340 & 323 & 408 & 472 & 408 & 8.0 & $* * *$ & NS & $* * *$ & $* * *$ \\
\hline ntake of $\mathrm{C}_{18 \cdot 2}(\mathrm{~g} / \mathrm{d})$ & 98 & 117 & 122 & 123 & 139 & 115 & 1.89 & $* * *$ & $* *$ & $* * *$ & $* * *$ \\
\hline ntake of $\mathrm{C}_{18: 3}(\mathrm{~g} / \mathrm{d})$ & 84 & 99 & 77 & 158 & 203 & 69 & 5.52 & $* * *$ & $\dagger$ & $* * *$ & $* * *$ \\
\hline 3iohydrogenation of $\mathrm{C}_{18: 2}(\%)^{6}$ & 86.5 & 85.1 & 83.2 & 83.2 & 76.7 & 86.7 & 1.45 & $* * *$ & $* * *$ & $* * *$ & $*$ \\
\hline 3iohydrogenation of $\mathrm{C}_{18 \cdot 3}(\%)^{6}$ & 94.3 & 91.5 & 86.1 & 93.6 & 91.6 & 89.4 & 0.80 & $* * *$ & $* * *$ & $* * *$ & ** \\
\hline Jumber & 4 & 3 & 3 & 4 & 2 & 3 & - & - & - & - & - \\
\hline Duodenal flow of $\mathrm{C}_{18: 0}(\mathrm{~g} / \mathrm{d})$ & 210 & 214 & 202 & 240 & $27 \overline{3}$ & 217 & 16.3 & NS & NS & $* * *$ & $\dagger$ \\
\hline Duodenal flow of $c i s-9 \mathrm{C}_{18.1}(\mathrm{~g} / \mathrm{d})$ & 18.2 & 20.5 & 23.5 & 24.4 & 34.0 & 21.9 & 2.30 & $* * *$ & $* *$ & $* * *$ & $\dagger$ \\
\hline Duodenal flow of trans- $11 \mathrm{C}_{18 \cdot 1}(\mathrm{~g} / \mathrm{d})$ & 16.8 & 18.5 & 20.3 & 20.0 & 21.5 & 20.6 & 2.38 & NS & NS & NS & NS \\
\hline Duodenal flow of cis-9, trans-11 $\mathrm{C}_{18: 2}(\mathrm{~g} / \mathrm{d})$ & 1.84 & 2.45 & 3.93 & 1.81 & 1.71 & 2.04 & 0.312 & **** & **** & **** & $* * *$ \\
\hline Duodenal flow of $\mathrm{C}_{18 \cdot 2}(\mathrm{~g} / \mathrm{d})$ & 11.6 & 14.3 & 17.0 & 15.7 & 23.7 & 14.1 & 1.56 & $* * *$ & $* * *$ & $* * *$ & * \\
\hline Duodenal flow of $\mathrm{C}_{18: 3}(\mathrm{~g} / \mathrm{d})$ & 4.75 & 6.63 & 10.42 & 7.63 & 14.21 & 7.03 & 1.356 & $* * *$ & $* * *$ & * & NS \\
\hline Biohydrogenation of $\mathrm{C}_{18: 2}(\%)^{7}$ & 88.5 & 87.9 & 86.5 & 87.1 & 83.3 & 87.7 & 1.33 & $\dagger$ & $*$ & * & NS \\
\hline Biohydrogenation of $\mathrm{C}_{18: 3}(\%)^{7}$ & 95.2 & 93.3 & 88.5 & 95.1 & 93.3 & 90.2 & 1.02 & $* * *$ & * & * & $*$ \\
\hline
\end{tabular}

${ }^{1} \mathrm{G}=$ grass silage; $\mathrm{RC}=$ red clover silage; $\mathrm{WC}=$ white clover silage; $\mathrm{A}=$ alfalfa silage; $\mathrm{GRC}=$ mixture of $\mathrm{G}$ and $\mathrm{RC}(50 / 50, \mathrm{DM}$ basis $)$; GWC = mixture of $\mathrm{G}$ and $\mathrm{WC}(50 / 50$, DM basis).

NS, not significant $(\mathrm{P}>0.1)$.

$\dagger P<0.1$.

$* P<0.05$

$* * * P<0.001$.

${ }^{2}$ Group $=\mathrm{G}$ vs. A vs. clover-containing diets (3-way comparison).

${ }^{3}$ Clover $\%=50$ vs. $100 \%$ inclusion of clover (within clover-containing diets).

${ }^{4}$ Clover species $=$ RC vs. WC (within clover-containing diets).

${ }^{5}$ Clover $\% \times$ clover species interaction.

${ }^{6}$ Biohydrogenation is calculated according to the change in proportion of total $\mathrm{C}_{18}$ fatty acids between feed and duodenal digesta (Wu et al., 1991).

${ }^{7}$ Alternatively, biohydrogenation is calculated from the measured intake and duodenal flow of the specific fatty acid ((intake-flow)/intake). 
Table 6. Water-solubility (\%) of Nitrogen in grass and clover silages (Experiment 2). Values are means with SD.

\begin{tabular}{ll}
\hline Crop & $\begin{array}{l}\text { Nitrogen } \\
\text { solubility }(\%)\end{array}$ \\
\hline Grass & $60.6(0.25)$ \\
Grass/Red clover & $56.7(0.11)$ \\
Red clover & $49.2(0.22)$ \\
White clover & $61.9(0.23)$ \\
\hline
\end{tabular}

was highest for treatments with highest rumen passage rates, WC and A. This latter effect would be expected according to conventional microbial energetics (Pirt, 1965), if high rumen passage rates of DM are associated with higher microbial growth rates.

Microbial energetic efficiency was highest for cows offered alfalfa silage, though the significantly lower apparent digestion of $\mathrm{OM}$ in the rumen with this diet led to low overall conversion of rumen degradable $\mathrm{N}$ into microbial $\mathrm{N}$ with this diet. The high levels of excess rumen degradable $\mathrm{N}$ for diets based on white clover silage and alfalfa silage (Table 4) explain why high microbial efficiencies were not associated with high $\mathrm{N}$ use efficiency (Dewhurst et al., 2003: Table 7). The high $\mathrm{N}$-use efficiency of white clover silage, at a given $\mathrm{N}$ intake (Dewhurst et al., 2003: Figure 1) may also result from improved energy supply to the cow, as reflected in higher milk yields (Table 1; Dewhurst et al., 2003: Table 7).

Duodenal NAN has three components: microbial N, rumen undegraded $\mathrm{N}$ (RUN), and endogenous $\mathrm{N}$, and it is necessary to estimate endogenous $\mathrm{N}$ flows in order to identify possible effects on flows of RUN. The lower NDF content and higher passage rates of legumes suggest that endogenous $\mathrm{N}$ losses could be lower than for grass silage (Lammers-Wienhoven et al., 1998), so it seems likely that the largest contribution to increased duodenal NAN with legume silages is from RUN.

Experiment 1 was designed so that the diet with the lowest protein content (based on grass silage) was not protein deficient. Consequently, all other diets con- tained an excess of protein, as was demonstrated by the very high rumen ammonia concentrations recorded for diets based on pure legume silages. This design makes it difficult to assess $\mathrm{N}$ utilization solely on the basis of production responses, so we have used in sacco and in vivo techniques to provide further information about $\mathrm{N}$ utilization.

The higher rate of degradation of DM and $\mathrm{N}$ from WC compared with G (Tables 7 and 8 respectively) is consistent with results obtained with fresh herbage (4wk regrowths) by Beever et al. (1986). However, the nylon bag technique revealed only small differences in $\mathrm{N}$ degradability between forages. Simple water solubility measurements (Table 6) were more revealing and showed an $18.8 \%$ lower $\mathrm{N}$ solubility for red clover silage than for grass silage. This effect is at the low end of the range of effects (19.9 to 43.5\% reduction in nonprotein $\mathrm{N}$ content (\% of total-N)) noted in a series of studies comparing red clover and alfalfa silages (Albrecht and Muck, 1991; Owens et al., 1999; Broderick et al., 2001). The similarity of the "a" fractions for $\mathrm{N}$ in all of the silages was contrary to the $\mathrm{N}$ solubility results and suggests that there may be a problem with loss of small particles from the dried clover silages through the pores of the nylon bags (Dewhurst et al., 1995).

Although there were no significant differences in the in vivo estimates of $\mathrm{N}$ degradability (Table 4), values were numerically lower for RC and GRC, possibly as a result of reduced proteolysis during ensiling brought about by the action of polyphenol oxidase in red clover (Albrecht and Muck, 1991). Nitrogen degradabilities were also low for WC, probably as a result of the high rumen passage rate with this diet. The lack of statistical significance between $\mathrm{N}$ degradabilities is probably the results of the inherent technical difficulties and assumptions (e.g. about endogenous-N content of digesta) involved in making these estimates.

The higher utilization of dietary $\mathrm{N}$ from white clover silage (at a given level of $\mathrm{N}$ intake), noted by Dewhurst et al. (2003: Figure 1) appears to reflect the combination of higher rumen passage rates, and the improved en-

Table 7. Dry matter degradation parameters estimated using the model of Dhanoa (1988) (Experiment 2). $\mathrm{SE}$ are given in brackets.

\begin{tabular}{llllrl}
\hline Crop & & & & & \multicolumn{1}{l}{$\begin{array}{l}\text { Effective } \\
\text { degradability }^{2}(\%)\end{array}$} \\
\hline Grass & $4.5(2.24)$ & $40.4(1.48)$ & $52.5(11.96)$ & $3.3(1.54)$ & 66.7 \\
Grass/Red clover & $4.6(2.15)$ & $41.0(1.52)$ & $41.2(6.67)$ & $4.7(1.89)$ & 65.1 \\
Red clover & $3.3(1.16)$ & $39.2(2.17)$ & $43.9(4.44)$ & $6.5(1.57)$ & 68.4 \\
White clover & $4.6(2.22)$ & $48.3(2.22)$ & $35.6(4.43)$ & $10.6(5.02)$ & 75.5 \\
\hline
\end{tabular}

\footnotetext{
${ }^{1}$ Fitted model: lag is the time before disappearance of material which does not disappear immediately, a is the fraction which disappears immediately, $\mathrm{b}$ is the fraction which disappears over time, and $\mathrm{c}$ is the rate of disappearance of the 'b' fraction.

${ }^{2}$ Assuming Outflow Rate $=3.3 \% / \mathrm{h}$
} 
Table 8. Nitrogen degradation parameters estimated using the model of Ørskov and McDonald (1979) (Experiment 2). SE are given in brackets.

\begin{tabular}{lllll}
\hline Crop & $\mathrm{a}^{1}+\mathrm{b}^{1}(\%)$ & $\mathrm{b}^{1}(\%)$ & $\mathrm{c}^{1}(\% / \mathrm{h})$ & $\begin{array}{l}\text { Effective } \\
\text { degradability }\end{array}$ \\
\hline Grass & $89.7(7.27)$ & $21.7(6.47)$ & $3.1(1.37)$ & 78.5 \\
Grass/Red clover & $92.6(4.00)$ & $28.6(3.45)$ & $4.2(1.59)$ & 80.0 \\
Red clover & $98.2(4.09)$ & $40.0(3.54)$ & $4.6(2.13)$ & 81.6 \\
White clover & $93.5(3.20)$ & $24.8(3.06)$ & $6.3(3.76)$ & 85.0 \\
\hline
\end{tabular}

\footnotetext{
${ }^{1}$ Fitted model: $\mathrm{a}$ is the fraction which disappears immediately, $\mathrm{b}$ is the fraction which disappears over time, and $c$ is the rate of disappearance of the ' $b$ ' fraction.

${ }^{2}$ Assuming Outflow Rate $=3.3 \% / \mathrm{h}$.
}

ergy supply with this diet. Higher passage rates may lead to reduced $\mathrm{N}$ degradability, despite the inherent higher degradability of $\mathrm{N}$ from WC when studies in nylon bags. Milk protein production was limited by energy supply- this restriction was reduced by the higher intakes and digestibility of white clover silage. Although the level of biohydrogenation of polyunsaturated fatty acids was high for all forage treatments, there were significant differences between diets that suggest possible approaches to increase delivery of these beneficial fatty acids from feed into milk. Biohydrogenation of both $\alpha$-linolenic and linoleic acids (Table 5 ) was highest with the grass silage-based diet, and the increased rumen passage rates of legume silages may have conferred some advantage in reducing the period in which feed was present in the rumen and consequently susceptible to biohydrogenation. The reduced biohydrogenation of $\alpha$-linolenic acid with the diet based on red clover silage is consistent with other results from our laboratory (Lee et al., 2003) and with the increased recovery of dietary $\alpha$-linolenic acid in milk (Dewhurst et al., 2003). Although the biohydrogenation of $\alpha$-linolenic acid was still high with the red clover silage-based diet, there was a $240 \%$ increase in the proportion of $\alpha$-linolenic acid passing through the rumen. Additional studies are needed to understand the mechanism of this effect, which might identify further potential to exploit this natural, low-cost and traceable source of beneficial fatty acids.

\section{CONCLUSIONS}

The high intake characteristics of legume silages are the result of different mechanisms: high rates of particle breakdown and passage with $\mathrm{A}$, and high rates of fermentation and passage with WC. There was some evidence for reduced $\mathrm{N}$ degradation in the rumen with $\mathrm{RC}$, possibly as a consequence of polyphenol oxidase activity, and with $\mathrm{WC}$, probably as a consequence of high rates of passage from the rumen. High passage rates of legume silages also led to increased microbial efficiency, but excess RDN led to low $\mathrm{N}$-use efficiency for diets based on white clover silage and alfalfa. Further studies are needed to balance the levels and types of supplements for legume silages in order to optimize $\mathrm{N}$ utilization. The increased content of $\alpha$-linolenic acid in milk from cows offered $\mathrm{RC}$ reflects a significant reduction in rumen biohydrogenation of this fatty acid.

\section{ACKNOWLEDGMENTS}

The financial support of the EU (project FAIR-CT961832), and the Ministry of Agriculture, Fisheries and Food (Department for Environment, Food and Rural Affairs) is gratefully acknowledged. The authors acknowledge the skilled technical assistance of staff at Trawsgoed Research Farm as well as in the Ruminant Nutrition and Analytical Chemistry laboratories.

\section{REFERENCES}

Albrecht, K. A., and R. E. Muck. 1991. Proteolysis in ensiled forage legumes that vary in tannin concentration. Crop Sci. 31: 464-469.

Albrecht, K. A., and G. A. Broderick. 1992. Ruminal in vitro degradation of protein from different legume species. Pages 92-94 in Research Summaries: US Dairy Forage Research Center, Madison, WI.

Bartram, C. G. 1987. The endogenous protein content of ruminant proximal duodenal digesta. Ph.D. thesis, University of Nottingham, UK.

Baumont, R., and A. G. Deswysen. 1991. Mélange et propulsion du contenu du réticulo-rumen. [The mixing and propulsion of reticulo-rumen content.] In French with English summary. Reprod. Nutr. Dev. 31:335-339.

Beever, D. E., M. S. Dhanoa, H. R. Losada, R. T. Evans, S. B. Cammell, and J. France. 1986. The effect of forage species and stage of harvest on the processes of digestion occuring in the rumen of cattle. Br. J. Nutr. 56:439-454.

Beever, D. E., H. R. Losada, D. L. Gale, M. C. Spooner, and M. S. Dhanoa. 1987. The use of monensin or formaldehyde to control the digestion of the nitrogen constituents of perennial ryegrass (Lolium perenne $\mathrm{cv}$. Melle) and white clover (Trifolium repens $\mathrm{cv}$. Blanca) in the rumen of cattle. Br. J. Nutr. 57:57-67.

Broderick, G. A., R. P. Walgenbach, and E. Sterrenburg. 2000. Performance of lactating dairy cows fed alfalfa or red clover silage as the sole forage. J. Dairy Sci. 83:1543-1551.

Broderick, G. A., R. P. Walgenbach, and S. Maignan. 2001. Production of lactating dairy cows fed alfalfa or red clover silage at equal dry matter or crude protein contents in the diet. J. Dairy Sci. 84:1728-1737. 
Castle, M. E., D. Reid, and J. N. Watson. 1983. Silage and milk production: studies with diets containing white clover silage. Grass For. Sci. 38:193-200.

Cozzi, G., G. Bittante, and C.E. Polan. 1993. Comparison of fibrous materials as modifiers of in situ ruminal degradation of corn gluten meal. J. Dairy Sci. 76:1106-1113.

Dewhurst, R. J., D. Hepper, and A. J. F. Webster. 1995. Comparison of in sacco and in vitro techniques for estimating the rate and extent of rumen fermentation of a range of dietary ingredients. Anim. Feed Sci. Technol. 51:211-229.

Dewhurst, R. J., J. M. Moorby, M. S. Dhanoa, R. T. Evans, and W. J. Fisher. 2000. Effects of altering energy and protein supply to dairy cows during the dry period. 1 . Intake, body condition, and milk production. J. Dairy Sci. 83:1782-1794.

Dewhurst, R. J., W. J. Fisher, J. K. S. Tweed, and R. J. Wilkins. 2003. Comparison of grass and legume silages for milk production. 1. Production responses with different levels of concentrate. J. Dairy Sci. 86:2598-2611.

Dhanoa, M. S. 1988. On the analysis of dacron bag data for low degradability feeds. Grass For. Sci. 43:441-444.

Evans, R. T., K. V. Skelton, and D. E. Beever. 1981. Portable equipment for the automatic sampling of duodenal contents from housed or grazing cattle. Lab. Pract. 30: 997-1000.

Hoffman, P. C., D. K. Combs, and M. D. Casler. 1998. Performance of lactating dairy cows fed alfalfa silage or perennial ryegrass silage. J. Dairy Sci. 81:162-168.

Lammers-Wienhoven, S. C. W., J. Voigt, L. Ram, J. Van Bruchem, J. Ketelaars, and S. Tamminga. 1998. Effect of cell walls, dry matter and protein supply on endogenous nitrogen flow in the small intestine of sheep. J. Anim. Physiol. Anim. Nutr. 79:225236 .

Lee, M. R. F., L. J. Harris, R. J. Dewhurst, R. J. Merry, and N. D. Scollan. 2003. The effect of clover silages on long chain fatty acid rumen transformations and digestion in beef steers. Anim. Sci. $76: 491-501$.
Merry, R. J., and A. B. McAllan. 1983. A comparison of the chemical composition of mixed bacteria harvested from the liquid and solid fractions of rumen digesta. Br. J. Nutr. 50:701-709.

Moseley. G., and J. R. Jones. 1984. The physical digestion of perennial ryegrass (Lolium perenne) and white clover (Trifolium repens) in the foregut of sheep. Br. J. Nutr. 52:381-390.

Ørskov, E. R., and McDonald, I. M. 1979. The estimation of protein degradability in the rumen from incubation measurements weighted according to rate of passage. J. Agric. Sci. (Camb.). 92:499-503.

Owens, V. N., K. A. Albrecht, and R. E. Muck. 1999. Protein degradation and ensiling characteristics of red clover and alfalfa wilted under varying levels of shade. Can. J. Plant Sci. 79:209-222.

Pirt, S. J. 1965. The maintenance energy of bacteria in growing cultures. Proc. Royal Soc. B 163:224-231.

Siddons, R. C., D. E. Beever and J. V. Nolan. 1982. A comparison of methods for the estimation of microbial nitrogen in duodenal digesta of sheep. Br. J. Nutr. 48:377-389.

Sukhija, P. S, and D. L. Palmquist. 1988. Rapid method for the determination of total fatty acid content and composition of feedstuffs and feces. J. Agric. Food Chem. 36:1202-1206.

Thomas, C., K. Aston, and S. R. Daley. 1985. Milk production from silage. 3. A comparison of red clover with grass silage. Anim. Prod. 41:23-31.

Waghorn, G. C., I. D. Shelton, and V. J. Thomas. 1989. Particle breakdown and rumen digestion of fresh ryegrass (Lolium perenne L.) and lucerne (Medicago sativa L.) fed to cows during a restricted feeding period. Br. J. Nutr. 61:409-423

Wilson, J. R., and P. M. Kennedy. 1996. Plant and animal constraints to voluntary feed intake associated with fibre characteristics and particle breakdown and passage in ruminants. Aust. J. Agric. Res. 47:199-225.

Wu, Z., O. A. Ohajuruka, and D. L. Palmquist. 1991. Ruminal synthesis, biohydrogenation, and digestibility of fatty acids by dairy cows. J. Dairy Sci. 74: 3025-3034. 